\title{
Determination of Trace Silver in Water Samples by Online Column Preconcentration Flame Atomic Absorption Spectrometry Using Termite Digestion Product
}

\author{
Joyce Nunes Bianchin, Edmar Martendal, and Eduardo Carasek \\ Departamento de Química, Universidade Federal de Santa Catarina, Florianópolis 88040-900, SC, Brazil \\ Correspondence should be addressed to Eduardo Carasek, ecarasek@hotmail.com
}

Received 12 October 2010; Revised 8 December 2010; Accepted 10 April 2011

Academic Editor: Bernd Hitzmann

Copyright (C) 2011 Joyce Nunes Bianchin et al. This is an open access article distributed under the Creative Commons Attribution License, which permits unrestricted use, distribution, and reproduction in any medium, provided the original work is properly cited.

A new method for Ag determination in water samples using solid phase extraction (SPE) coupled to a flow injection system and flame atomic absorption spectrometry was developed. The sorbent used for Ag preconcentration and extraction was the termite digestion product. Flow and chemical variables of the system were optimized through a multivariate procedure. The factors selected were adsorbent mass, buffer type and concentration, sample $\mathrm{pH}$, and sample flow rate. The detection limit and precision were $3.4 \mu \mathrm{g} \mathrm{L}^{-1}$ and $3.8 \%\left(n=6,15 \mu \mathrm{g} \mathrm{L}^{-1}\right)$, respectively. The enrichment factor and the linear working range were, respectively, 21 and $10-50 \mu \mathrm{g} \mathrm{L}{ }^{-1}$. Results for recovery tests using different water samples were between 96 and $107 \%$. The proposed methodology was applied with success for the determination of Ag in water used to wash clothes impregnated with silver nanoparticles, supplied by a factory located in Santa Catarina, Brazil.

\section{Introduction}

Nanotechnology and science are directed toward processes, materials, and products in the 1 to $100 \mathrm{~nm}$ scale, and they have favored certain industrial segments, including foodstuffs, electronics, textiles, pharmaceuticals, biotechnological, cosmetics, medicine, agriculture, and national security $[1-5]$.

One of the most well-known nanoproducts is the silver nanoparticle [6], which is widely used in the textile industry in Brazil. Water- or oil-resistant and antibacterial clothes are some examples of the application of nanotechnology in this industry [5]. However, the attractive properties of the nanomaterials, such as small particle size, varied shape and high superficial area, may lead to their causing damage to living organisms [7-11]. Some studies have reported that prolonged ingestion of nanosilver can induce a rare disease which causes irreversible pigmentation of the skin [4].

In this context the development of analytical techniques for the determination of silver in several kinds of samples has been attracting the attention of many researcher groups
[12-22]. Solid phase extraction (SPE) [23], liquid-liquid extraction [24], and liquid membrane extraction [25] are widely applied for the separation and preconcentration of metals, among a variety of other methods. In particular, the procedures based on SPE offer some advantages over the others, such as less waste generation, milder matrix effects, availability and easy recovery of the solid phase, achievement of higher preconcentration factors, easy adaptation of the solid phase in a minicolumn coupled to a continuous flow preconcentration system, and, in general, no requirement for the use of toxic solvents [26]. Another important advantage of this technique is the possibility to use a relatively simple detection system, such as FAAS, rather than techniques without flame, which require more sophisticated equipment.

Flow injection (FI) online separation and preconcentration with minicolumns containing an appropriate adsorbent is an area that has shown great promise and, in fact, has become one of the most active research fields in automated solution analysis in recent years [27]. This method offers some very favorable features in relation to batch systems, such as higher sample throughput, better 
efficiency and enrichment reproducibility, low reagent and sample consumption, lower risk of contamination, and simple automated operation. Currently, many FI online preconcentration systems have been coupled with the FAAS technique, due to the low cost of this equipment and its high analytical velocity [28].

There are many materials found in the environment formed by macromolecules containing several functional groups which are able to interact with metals through different phenomena such as adsorption, chemisorption, complexation, and ion exchange. The materials with these characteristics are known as biosorbents [29], and they can be applied in SPE procedures in an FI system.

Our research group has been exploring the use of new biosorbent materials for metal determination in biological and environmental matrices. Among the biosorbents explored are vermicompost [30], Moringa oleifera seeds [31], and, currently, the termite digestion product.

Termite digestion product is produced through the biochemical transformation of cellulose that occurs inside the termite intestine with the help of protozoa. This product is released in small cylindrical-shaped particles with active sites on their surface that can be deprotonated according to the $\mathrm{pH}$, leaving their surface negatively charged, thus facilitating the interaction with metallic ions. Due to its appropriate and monodispersive particle size distribution, the termite digestion product can be easily accommodated in an SPE cartridge.

In this study, the use of termite digestion product for the determination of silver in the wash water of clothes impregnated with silver nanoparticle using an FI online preconcentration system coupled with FAAS is proposed. In addition, the optimization of this system was carried out using a multivariate methodology.

\section{Experimental}

2.1. Instrumentation. A Varian SpectrAA 50 (Victoria, Australia) flame atomic absorption spectrometer (FAAS), equipped with a silver hollow cathode lamp and a deuterium lamp for background correction, was used for the detection of silver. The instrument was operated under the conditions recommended by the manufacturer. A Mettler Toledo 320 $\mathrm{pH}$ meter was used to adjust the $\mathrm{pH}$ of the samples and working solutions. An Ismatec-IPC (Zurich, Switzerland) peristaltic pump equipped with eight channels and Tygon and polyethylene tubes was used to pump the solutions through the minicolumn $(60 \mathrm{~mm} \times 3 \mathrm{~mm})$ in the elution and preconcentration steps.

Infrared (IR) spectra were recorded on an ABB-Bomem Fourier transform-IR spectrometer, model FTLA 2000 using the $\mathrm{KBr}$ disc method. The $\mathrm{CHN}$ analysis was carried out on a CE Instruments, model EA 1110 CHNS elemental analyzer. Scanning electronic microscopy (Philips XL-30 microscope) and semiquantitative microanalysis using energy dispersion spectroscopy (EDS) were carried out to characterize the termite digestion product used as the biosorbent.

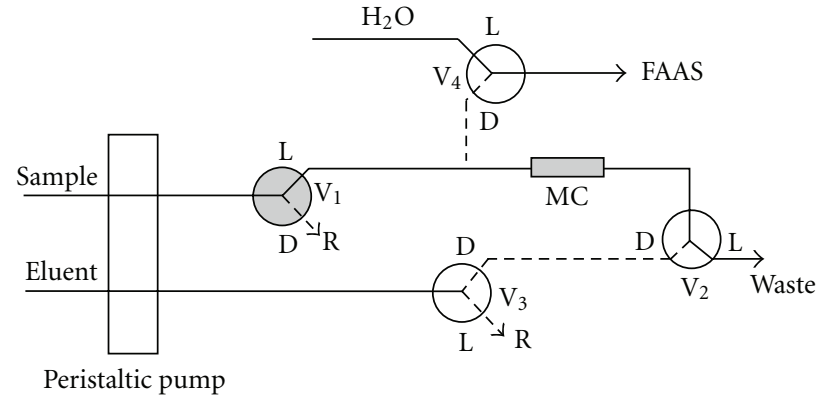

(a)

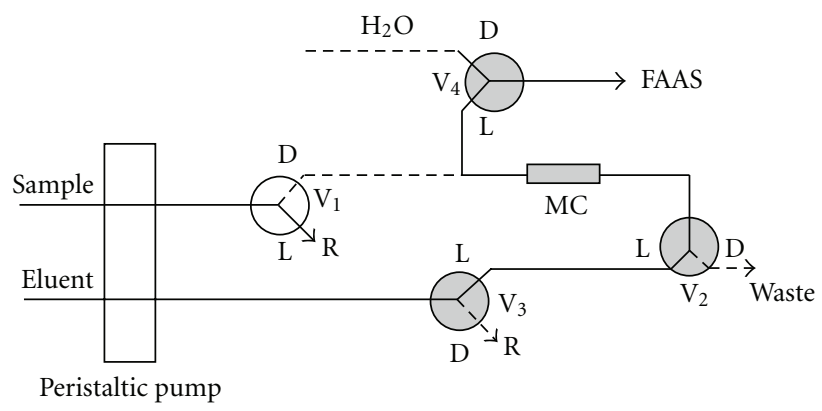

(b)

FIGURE 1: Diagram of the online preconcentration system used in this study. (a) adsorption process and (b) desorption process. V: valve, L: open way, D: closed way, MC: minicolumn containing the adsorbent, R: sample or eluent back stream, hatched circle: valve on, and white circle: valve off.

2.2. Chemicals. Ultrapure water from a Milli-Q (Millipore, Bedford, MA, USA) water purification system was used to prepare all solutions. All chemicals were of analytical grade and were used without previous purification. The laboratory glassware was washed with a 2\% (v/v) Extran (Merck, Darmstadt, Germany) solution, kept overnight in 10\% (v/v) nitric acid solution, and then washed with deionized water.

Working standard solutions of silver in appropriate concentrations were prepared daily by dilution of a $1000 \mathrm{mg} \mathrm{L}^{-1}$ $\mathrm{Ag}^{+}$stock solution (Fluka, Switzerland).

Nitric acid solutions (Merck) used as the eluent in the flow system were prepared by appropriate dilution of the concentrated acid with water.

Buffer solutions were prepared with appropriate amounts of ammonia (Merck), sodium citrate, sodium hydrogen phosphate, or tris(hydroxymethyl)aminomethane, the final $\mathrm{pH}$ being adjusted to the required value with $\mathrm{HCl}$ $6 \mathrm{~mol} \mathrm{~L}^{-1}$ or $\mathrm{NaOH} 6 \mathrm{~mol} \mathrm{~L}^{-1}$.

2.3. Preparation of the Samples. The wash water samples of clothes impregnated with silver nanoparticles were submitted to the following procedure: addition of $2 \mathrm{~mL}$ of concentrated nitric acid to $100 \mathrm{~mL}$ sample, magnetically stirring the solution for 24 hours. At this stage the silver nanoparticles were oxidized to $\mathrm{Ag}^{+}$, and the sample was submitted to the preconcentration system. 
2.4. Online Preconcentration System. The online flow system used for the development of the proposed method is shown in Figure 1. The flow system consists of a peristaltic pump equipped with Tygon tubes, four three-way solenoid valves, and a minicolumn filled with termite digestion product. The system was coupled to the FAAS. During the preconcentration step (Figure 1(a)) valve 1 is open and the other valves remain closed, the sample or working solutions are pumped through the minicolumn, and the effluent is discharged. In the elution step (Figure 1(b)), valve 1 is closed and valves 2, 3, and 4 are open. Thus, the eluent percolates through the minicolumn in the opposite direction to that of the preconcentration step. The eluate is carried directly to the nebulization system of the FAAS.

2.5. Point of Zero Charge. The point of zero charge was obtained preparing several $0.01 \mathrm{KCl} \mathrm{mol} \mathrm{L} \mathrm{L}^{-1}$ solutions $(50 \mathrm{~mL})$ with $\mathrm{pH}$ between 2 to 12 with and without $10 \mathrm{~g}$ of biosorbent. These solutions were periodically agitated, and, after $48 \mathrm{~h}$, their $\mathrm{pH}$ values were determined. A plot of $\Delta \mathrm{pH}$ versus $\mathrm{pH}_{\mathrm{KCl}}$ was obtained to calculate the point of zero charge. The $\Delta \mathrm{pH}$ was calculated as the difference between the $\mathrm{pH}$ of the solutions with and without the biosorbent. The $\mathrm{pH}_{\mathrm{KCl}}$ is the $\mathrm{pH}$ of the solutions without the biosorbent. The point of zero charge is the $\mathrm{pH}$ at which $\mathrm{pH}_{\mathrm{KCl}}$ and $\Delta \mathrm{pH}$ are zero.

\section{Results and Discussion}

In this study, $\mathrm{Ag}^{+}$is used to represent all of the chemical species containing silver ions. This study consisted of three steps: the first focused in the characterization of the biosorbent. In the second step, the optimum experimental conditions for the extraction of $\mathrm{Ag}$ from aqueous solutions using the new biosorbent in an online SPE system were determined through a multivariate optimization technique. In the last step, the analytical features of merit were obtained for the optimized online system using the termite digestion product as the biosorbent, and the proposed method was applied to the determination of silver from wash water samples of clothes impregnated with silver nanoparticles.

3.1. Characterization of the Biosorbent. Among the dry wood termites, the species that cause most damage in the world belong to the Cryptotermes genus, Cryptotermes brevis being the most commonly cited in Brazil [32]. The wood used in this study was Pine because of its high availability, and it is the kind of wood most frequently attacked by termites. Samples of the termite digestion product were collected from different sources, and their extraction capacity was tested using the analytical preconcentration methods proposed in this study. All biosorbents studied showed similar analytical response, indicating good tolerance limits in relation to the location and environment of production.

The FT-IR technique was used to study the main functional groups present in the termite digestion product, and the results are given in Figure 2. The spectrum shows a broadband centered at $3413.75 \mathrm{~cm}^{-1}$ assigned to $\mathrm{O}-\mathrm{H}$

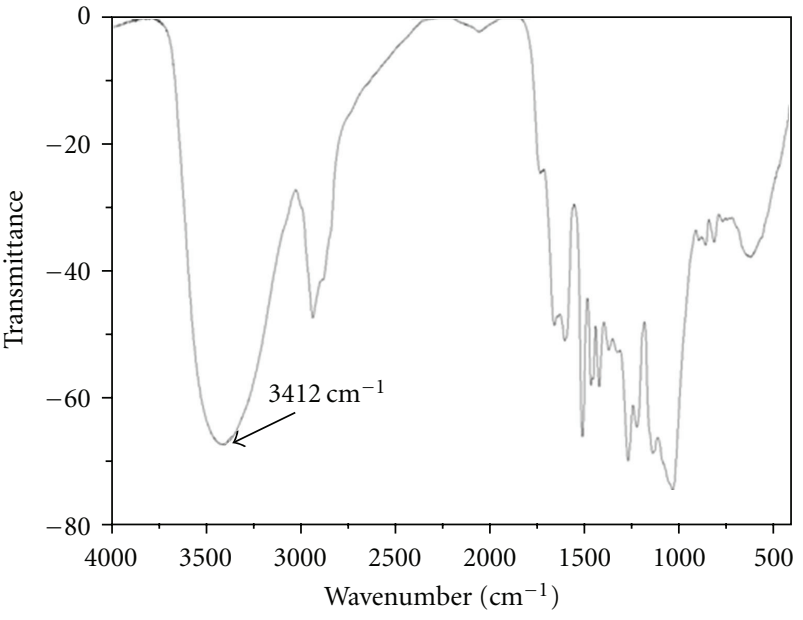

FIGURE 2: FT-IR spectrum of termite digestion product.

stretching. The expected presence of amine groups was not observed due to the low nitrogen concentration in the sample, approximately $1 \%$ of the total mass of sorbent. On the other hand, the elemental analysis results indicated $51.79 \% \mathrm{C}, 6.28 \% \mathrm{H}$, and $0.97 \% \mathrm{~N}$.

Considering that termites live on wood, which basically consists of cellulose, and observing the strong band assigned to $\mathrm{O}-\mathrm{H}$ stretching, it is suggested that these groups are responsible for electrostatic interactions between the sorbent and metals. This is verified by the existence of a point of zero charge for the termite digestion product.

Figure 3 shows the micrographs obtained by SEM for the termite digestion product. The surface of the proposed biosorbent has a compact morphology, without apparent porosity and with particles of regular size and a cylindrical shape. A semiquantitative analysis of the biosorbent surface was performed through EDS (Figure 4) and the spectrum showed peaks attributed to carbon, oxygen, and calcium, the latter being the counterion of the biosorbent active sites. Through the results obtained by elemental analysis and EDS, it can be estimated that the termite digestion product is composed of carbon (52\%), hydrogen (6\%), oxygen (39\%), nitrogen $(1 \%)$, and calcium $(2 \%)$.

The result obtained in the determination of the $\mathrm{pH}$ value of the point of zero charge for the proposed biosorbent is shown in Figure 5. As can be observed, the same number of positive and negative charges on the surface of the termite digestion product is observed at $\mathrm{pH}$ 5.8. Thus, to guarantee a negatively charged surface for the proposed biosorbent, a value of $\mathrm{pH}>5.8$ was used throughout the study.

3.2. Optimization of Chemical and Flow Parameters. The effect of buffer type (TRIS/HCl, $\mathrm{HPO}_{4}{ }^{-2} / \mathrm{H}_{2} \mathrm{PO}_{4}{ }^{-}, \mathrm{NH}_{3} /$ $\mathrm{NH}_{4}{ }^{+}$, and citrate) on the extraction efficiency of the proposed online preconcentration system was studied using the univariate method. In this study the sample $\mathrm{pH}$ was changed for each buffer in order to investigate the interaction between them. According to the results shown in Figure 6, the maximum retention for silver occurred with $\mathrm{NH}_{3} / \mathrm{NH}_{4}{ }^{+}$ 


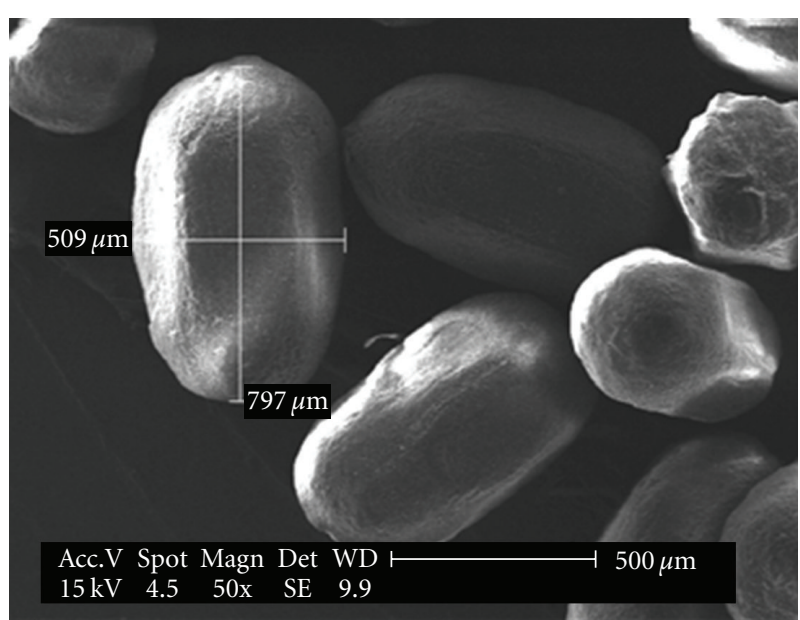

(a)

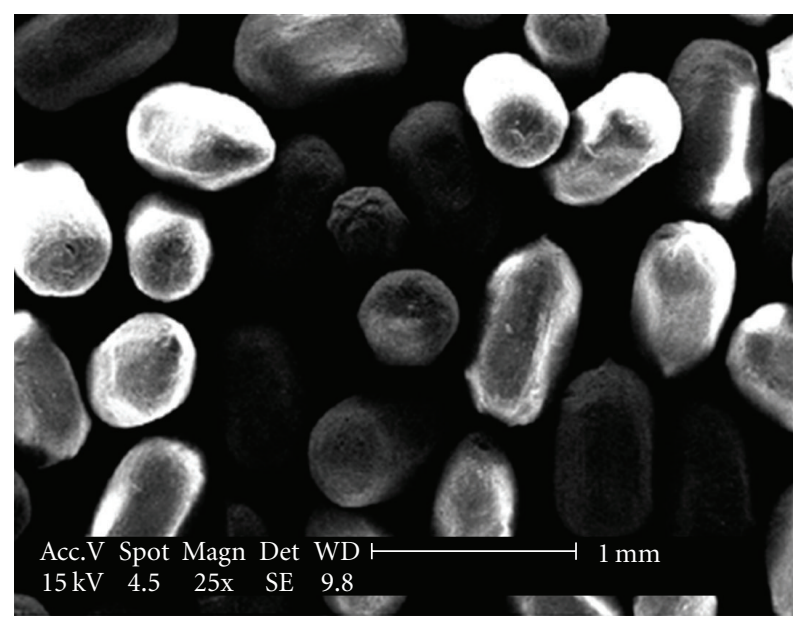

(b)

FIGURE 3: SEM micrographs of termite digestion product.

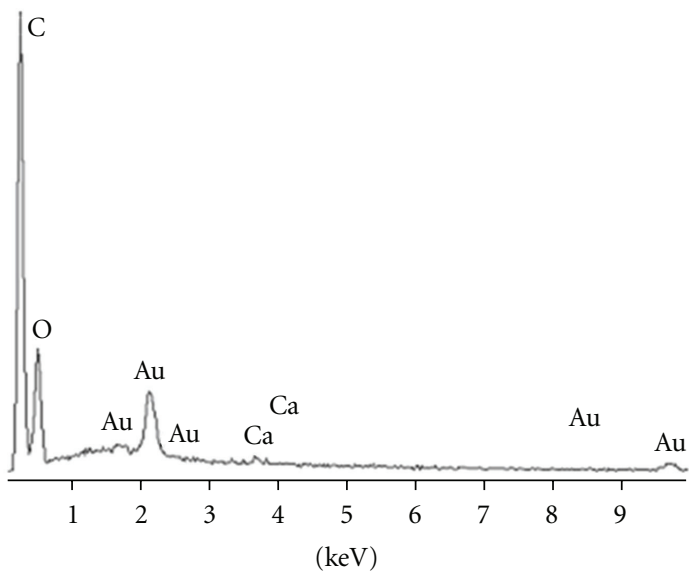

Element

$$
\begin{array}{cl}
\mathrm{C} & 57.3 \% \\
\mathrm{O} & 40.97 \% \\
\mathrm{Ca} & 1.73 \%
\end{array}
$$

Figure 4: Energy dispersion microanalysis (EDS) of the termite digestion product.

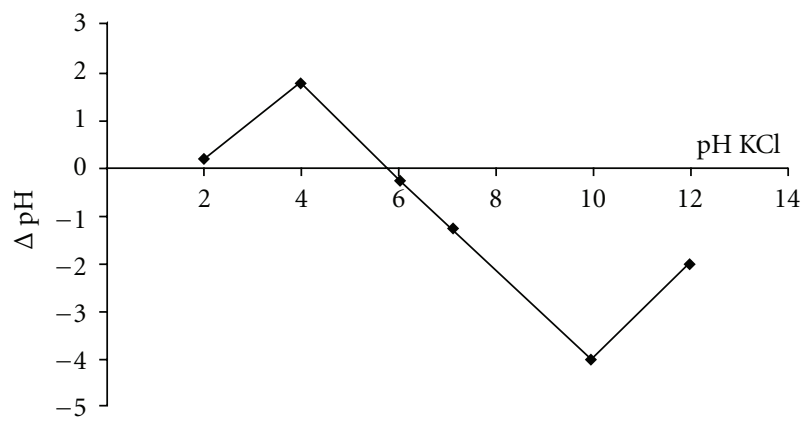

FIGURe 5: Plot of $\mathrm{pH}_{\mathrm{KCl}}$ and $\Delta \mathrm{pH}$ to obtain the point of zero charge for the proposed sorbent.

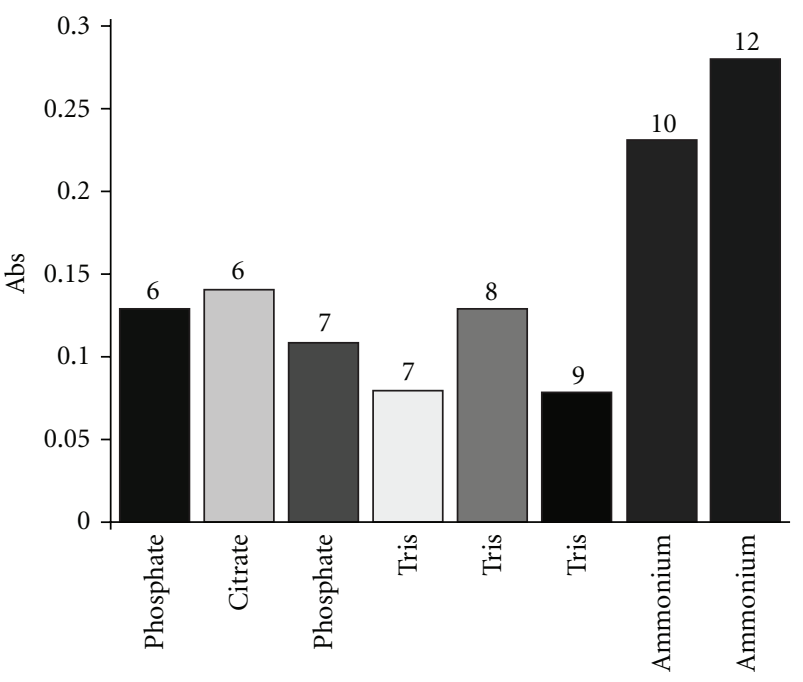

Buffer type

Figure 6: Effect of buffer type on the extraction efficiency of Ag using termite digestion product.

buffer and a sample $\mathrm{pH}$ of 12 . In this case, there is the possibility for the formation of a positively charged silver amino complex, which can be retained by the biosorbent and would lead to higher extraction efficiency. In addition, the formation of a complex between silver ion and $\mathrm{NH}_{3}$ prevents the precipitation of $\mathrm{Ag}^{+}$as $\mathrm{Ag}_{2} \mathrm{O}_{(\mathrm{s})}$, explaining the better performance of ammonium buffer compared to the other buffers.

A Pareto chart was plotted to check the influence of the factors and their interactions in the system using the proposed biosorbent. The factors chosen considering the online preconcentration system were biosorbent mass $(30-300 \mathrm{mg}$ ), sample $\mathrm{pH}(8-12), \mathrm{NH}_{3} / \mathrm{NH}_{4}{ }^{+}$buffer concentration (0.01$\left.0.1 \mathrm{~mol} \mathrm{~L}^{-1}\right)$, and sample flow rate $\left(4-8 \mathrm{~mL} \mathrm{~min}^{-1}\right)$. The silver concentration used in the optimization was $50 \mu \mathrm{g} \mathrm{L}^{-1}$. 


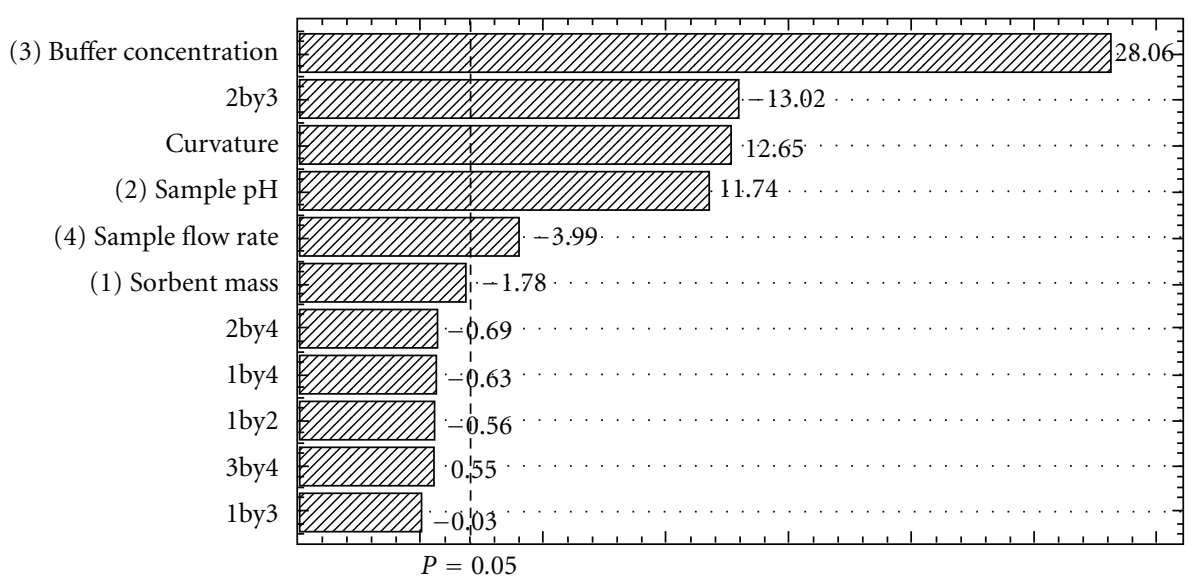

Figure 7: Pareto chart of standardized effects for variables (1: sorbent mass, 2: sample pH, 3: buffer concentration and 4: sample flow rate) and their interactions (2by4, 2by3, 1by3, 1by2, 1by4, and 3by4) in the Ag preconcentration.

The eluent flow rate was previously studied in the range of $4-8 \mathrm{~mL} \mathrm{~min}^{-1}$ and was not found to be a significant parameter in this system, thus being fixed at $8 \mathrm{~mL} \mathrm{~min}^{-1}$. The main effects and their interactions can be observed in the Pareto chart shown in Figure 7. According to this chart, the factors of sample $\mathrm{pH}$ and buffer concentration, and their interactions, are highly significant.

The positive values obtained for buffer concentration and sample $\mathrm{pH}$ in this study $(+28.06$ and +11.74 , resp. $)$ indicate that by increasing these factors the analytical signal will also increase. On the other hand, the negative value for sample flow rate indicates an improvement in the analytical response when the level changes from maximum to minimum. A low sample flow rate allows a better interaction between the analyte and the biosorbent surface increasing the extraction efficiency. However, the use of a low sample flow rate leads to a poor analytical frequency. Thus, an intermediate flow rate $\left(6 \mathrm{~mL} \mathrm{~min}^{-1}\right)$ was considered to be most appropriate and was used without lost of analytical signal. The factorial study also demonstrated that the biosorbent mass was not a significant factor and this parameter was fixed at $300 \mathrm{mg}$. The results obtained for the full factorial study indicated that the variables buffer concentration and sample $\mathrm{pH}$ required a final optimization. Therefore, the aforementioned variables were optimized using a Doehlert design.

The response surface was obtained, varying the sample $\mathrm{pH}(10-12)$ and buffer concentration $\left(0.1-0.5 \mathrm{~mol} \mathrm{~L}^{-1}\right)$, through application of the Doehlert matrix and is shown in Figure 8. These results indicate that when a high buffer concentration is used the sample $\mathrm{pH}$ can be within the range of 10 and 12 without lost of analytical signal, showing a robust characteristic for the proposed method. A high $\mathrm{NH}_{3} / \mathrm{NH}_{4}{ }^{+}$buffer concentration leads to the formation of a positively charged silver amino complex which could favor the interaction of the silver with the sample and biosorbent surface within the optimized sample $\mathrm{pH}$ range. Higher buffer concentration was not studied because, under these conditions, the analyte was quantitatively retained.

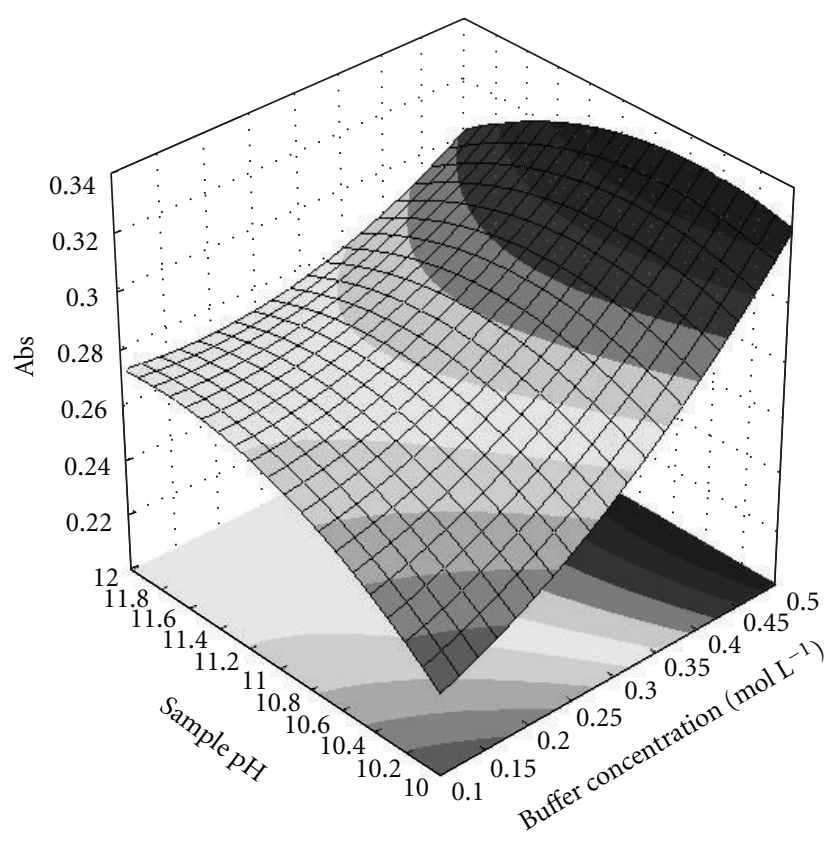

FIGURE 8: Response surface graph obtained from Ag extraction in aqueous samples using termite digestion product.

In short, the optimized conditions for the adsorption of Ag onto the termite digestion product in the proposed online system obtained using full factorial and Doehlert designs are $\mathrm{NH}_{3} / \mathrm{NH}_{4}{ }^{+}$buffer at $0.50 \mathrm{~mol} \mathrm{~L}^{-1}$, sample $\mathrm{pH}$ of $10-12$, and sample flow rate of $6.0 \mathrm{~mL} \mathrm{~min}^{-1}$.

3.3. Analytical Features of Merit. The performance of the preconcentration system using the termite digestion product as a biosorbent is shown in Table 1. Calibration curves for Ag were obtained using solutions in the concentration range of $0-50 \mu \mathrm{g} \mathrm{L}^{-1}$. The precision of the proposed method is evaluated as the relative standard deviation for a sample 
TABle 1: Performance data for silver determination by sorption on termite digestion product minicolumn using an FI system.

\begin{tabular}{lc}
\hline Parameter & \\
\hline Working range & $10-50 \mu \mathrm{g} \mathrm{L}^{-1}$ \\
Correlation coefficient $(R)$ & 0.99928 \\
Precision $\left(15 \mu \mathrm{g} \mathrm{L}^{-1}, n=6\right) \%$ & 3.7 \\
Precision $\left(35 \mu \mathrm{g} \mathrm{L}^{-1}, n=6\right) \%$ & 1.1 \\
Limit of detection & $3.4 \mu \mathrm{g} \mathrm{L}^{-1}$ \\
Enrichment factor & 21 \\
\hline
\end{tabular}

TABLE 2: Results obtained through the recovery tests.

\begin{tabular}{lcc}
\hline Sample & {$\left[\mathrm{Ag}^{+}\right] \mu \mathrm{g} \mathrm{L}^{-1}$} & Recovery\% \\
\hline 1 & 15.06 & 100.4 \\
2 & 14.37 & 95.8 \\
3 & 15.94 & 106.3 \\
4 & 14.46 & 96.4 \\
\hline
\end{tabular}

solution containing 15 and $35 \mu \mathrm{g} \mathrm{L}^{-1}$ of silver, when $10.0 \mathrm{~mL}$ of sample was preconcentrated. The limit of detection (LOD) is defined as the concentration of analyte that gives a response equivalent to three times the standard deviation (SD) of the blank $(n=10)$. The enrichment factor (EF) was calculated as the ratio of the slopes of the calibration curves obtained with and without preconcentration. The intercept and the slope of the curve with and without preconcentration, respectively, are shown below: Abs = $0.0069+0.0069 \mathrm{C}_{\mathrm{Ag}^{+}}$and $\mathrm{Abs}=0.0079+0.0003+\mathrm{C}_{\mathrm{Ag}^{+}}$.

3.4. Application of the Proposed Method for Silver Determination. The proposed method was applied to the analysis of water used to wash pillowcases impregnated with silver nanoparticles which were obtained from a textile industry located in Santa Catarina, Brazil. The concentration of the analyte in the wash water samples was below the detection limit of the method, as there was no spiking of the samples, and thus the metallic ions could not be detected. In order to evaluate the accuracy of the preconcentration procedure, recovery tests were carried out by adding $15 \mu \mathrm{g} \mathrm{L}^{-1}$ of Ag to all samples studied. The recovery of Ag obtained (Table 2) from this study was between $96-107 \%$.

\section{Conclusions}

The proposed online preconcentration system using a minicolumn filled with termite digestion product biosorbent represents an attractive alternative method to determine silver in aqueous samples. The online preconcentration procedure is simple and presented good sensitivity and precision in the determination of trace concentrations of Ag in the samples analyzed by FAAS.

The use of full factorial and Doehlert designs allowed the optimization of the proposed system, while taking the interactions among the variables into consideration. This procedure was found to be more efficient than the univariate method, and its development required a low number of experiments.

\section{Acknowledgments}

The authors are grateful to the Brazilian government agency Conselho Nacional de Desenvolvimento Cientifico e Tecnológico $(\mathrm{CNPq})$ for financial support. The authors would also like to state that this study was not supported by MilliQ, Millipore or Extran.

\section{References}

[1] M. N. Moore, "Do nanoparticles present ecotoxicological risks for the health of the aquatic environment?" Environment International, vol. 32, no. 8, pp. 967-976, 2006.

[2] C. J. Smith, B. J. Shaw, and R. D. Handy, "Toxicity of single walled carbon nanotubes to rainbow trout, (Oncorhynchus mykiss): respiratory toxicity, organ pathologies, and other physiological effects," Aquatic Toxicology, vol. 82, no. 2, pp. 94109, 2007.

[3] G. Federici, B. J. Shaw, and R. D. Handy, "Toxicity of titanium dioxide nanoparticles to rainbow trout (Oncorhynchus mykiss): gill injury, oxidative stress, and other physiological effects," Aquatic Toxicology, vol. 84, no. 4, pp. 415-430, 2007.

[4] X. Chen and H. J. Schluesener, "Nanosilver: a nanoproduct in medical application," Toxicology Letters, vol. 176, no. 1, pp. 112, 2008.

[5] P. Mariuzzo, "Diferenciação do produto: estratégia da indústria têxtil para enfrentar a concorrência estrangeira," Inovação Uniemp, vol. 3, pp. 6-9, 2007.

[6] M. M. da Silva Paula, C. S. da Costa, M. C. Baldin et al., "In vitro effect of silver nanoparticles on Creatine Kinase activity," Journal of the Brazilian Chemical Society, vol. 20, no. 8, pp. 1556-1560, 2009.

[7] Z. Tong, M. Bischoff, L. Nies, B. Applegate, and R. F. Turco, "Impact of fullerene (C60) on a soil microbial community," Environmental Science and Technology, vol. 41, no. 8, pp. 29852991, 2007.

[8] A. Magrez, S. Kasas, V. Salicio et al., "Cellular toxicity of carbon-based nanomaterials," Nano Letters, vol. 6, no. 6, pp. 1121-1125, 2006.

[9] E. Bermudez, J. B. Mangum, B. A. Wong et al., "Pulmonary responses of mice, rats, and hamsters to subchronic inhalation of ultrafine titanium dioxide particles," Toxicological Sciences, vol. 77, no. 2, pp. 347-357, 2004.

[10] M. Auffan, L. Decome, J. Rose et al., "In vitro interactions between DMSA-coated maghemite nanoparticles and human fibroblasts: a physicochemical and cyto-genotoxical study," Environmental Science and Technology, vol. 40, no. 14, pp. 4367-4373, 2006.

[11] E. Oberdörster, S. Zhu, T. M. Blickley, P. McClellan-Green, and M. L. Haasch, "Ecotoxicology of carbon-based engineered nanoparticles: effects of fullerene $\left(\mathrm{C}_{60}\right)$ on aquatic organisms," Carbon, vol. 44, no. 6, pp. 1112-1120, 2006.

[12] A. T. Wan, R. A. J. Conyers, C. J. Coombs, and J. P. Masterton, "Determination of silver in blood, urine, and tissues of volunteers and burn patients," Clinical Chemistry, vol. 37, no. 10, pp. 1683-1687, 1991. 
[13] M. P. Arena, M. D. Porter, and J. S. Fritz, "Rapid, low level determination of silver(I) in drinking water by colorimetricsolid-phase extraction," Analytica Chimica Acta, vol. 482, no. 2, pp. 197-207, 2003.

[14] C. S. T. Araújo, V. N. Alves, H. C. Rezende, and N. M. M. Coelho, "Development of a flow system for the determination of low concentrations of silver using Moringa oleifera seeds as biosorbent and flame atomic absorption spectrometry," Microchemical Journal, vol. 96, no. 1, pp. 82-85, 2010.

[15] M. Soylak and R. S. Cay, "Separation/preconcentration of silver(I) and lead(II) in environmental samples on cellulose nitrate membrane filter prior to their flame atomic absorption spectrometric determinations," Journal of Hazardous Materials, vol. 146, no. 1-2, pp. 142-147, 2007.

[16] J. L. Manzoori, H. Abdolmohammad-Zadeh, and M. Amjadi, "Ultra-trace determination of silver in water samples by electrothermal atomic absorption spectrometry after preconcentration with a ligand-less cloud point extraction methodology," Journal of Hazardous Materials, vol. 144, no. 1-2, pp. 458-463, 2007.

[17] M. C. Bruzzoniti, D. K. Kobylinska, M. Franko, and C. Sarzanini, "Flow injection method for the determination of silver concentration in drinking water for spacecrafts," Analytica Chimica Acta, vol. 665, no. 1, pp. 69-73, 2010.

[18] C. K. Christou and A. N. Anthemidis, "Flow injection online displacement/solid phase extraction system coupled with flame atomic absorption spectrometry for selective trace silver determination in water samples," Talanta, vol. 78, no. 1, pp. 144-149, 2009.

[19] M. Soylak, L. Elci, and M. Dogan, "A sorbent extraction procedure for the preconcentration of gold, silver and palladium on an activated carbon column," Analytical Letters, vol. 33, no. 3, pp. 513-525, 2000.

[20] M. Soylak and R. S. Cay, "Separation/preconcentration of silver(I) and lead(II) in environmental samples on cellulose nitrate membrane filter prior to their flame atomic absorption spectrometric determinations," Journal of Hazardous Materials, vol. 146, no. 1-2, pp. 142-147, 2007.

[21] M. Tuzen and M. Soylak, "Column solid-phase extraction of nickel and silver in environmental samples prior to their flame atomic absorption spectrometric determinations," Journal of Hazardous Materials, vol. 164, no. 2-3, pp. 1428-1432, 2009.

[22] M. Ghaedi, A. Shokrollahi, K. Niknam, E. Niknam, S. Derki, and M. Soylak, "A cloud point extraction procedure for preconcentration/flame atomic absorption spectrometric determination of silver, zinc, and lead at subtrace levels in environmental samples," Journal of AOAC International, vol. 92, no. 3, pp. 907-913, 2009.

[23] J. N. Bianchin, R. Mior, E. Martendal, J. S. Carletto, and E. Carasek, "Multivariate optimization and application of silica gel chemically modified with Niobium (V) oxide for the determination of $\mathrm{Ni}$ (II) in aqueous matrices in an on-line system," Ecletica Quimica, vol. 33, no. 4, pp. 25-32, 2008.

[24] I. Facchin and C. Pasquini, "Extração líquido-líquido em sistemas de fluxo," Química Nova, vol. 21, pp. 60-68, 1998.

[25] J. S. Carletto, R. M. Luciano, G. C. Bedendo, and E. Carasek, "Simple hollow fiber renewal liquid membrane extraction method for pre-concentration of $\mathrm{Cd}(\mathrm{II})$ in environmental samples and detection by Flame Atomic Absorption Spectrometry," Analytica Chimica Acta, vol. 638, no. 1, pp. 45-50, 2009.

[26] T. C. De Ávila, M. G. Segatelli, L. A. Beijo, and C. R. T. Tarley, "Employ of silica gel organically modified and ionically imprinted for selective on-line preconcentration of copperions," Quimica Nova, vol. 33, no. 2, pp. 301-308, 2010.

[27] D. B. Koleva and E. H. Ivanovab, "Flow injection analysis with atomic spectrometric detection," European Journal of Clinical Chemistry, vol. 3, pp. 183-211, 2008.

[28] R. L. Dutra, H. F. Maltez, and E. Carasek, "Development of an on-line preconcentration system for zinc determination in biological samples," Talanta, vol. 69, no. 2, pp. 488-493, 2006.

[29] A. Demirbas, "Heavy metal adsorption onto agro-based waste materials: a review," Journal of Hazardous Materials, vol. 157, no. 2-3, pp. 220-229, 2008.

[30] J. N. Bianchin, E. Martendal, R. Mior et al., "Development of a flow system for the determination of cadmium in fuel alcohol using vermicompost as biosorbent and flame atomic absorption spectrometry," Talanta, vol. 78, no. 2, pp. 333-336, 2009.

[31] V. N. Alves, R. Mosquetta, N. M. M. Coelho et al., "Determination of cadmium in alcohol fuel using Moringa oleifera seeds as a biosorbent in an on-line system coupled to FAAS," Talanta, vol. 80, no. 3, pp. 1133-1138, 2010.

[32] E. S. R. Eleotério and E. Berti Filho, "Levantamento e identificação de cupins (Insecta: Isoptera) em área urbana de Piracicaba, SP," Ciência Floresta, vol. 10, pp. 125-139, 2000. 


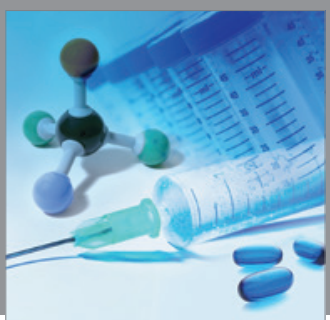

International Journal of

Medicinal Chemistry

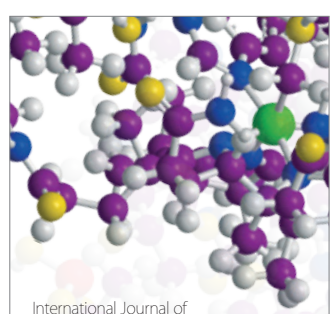

Carbohydrate Chemistry

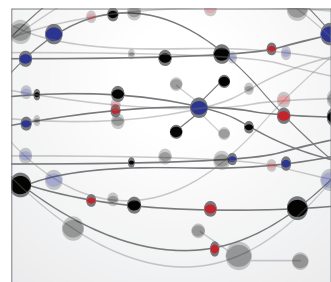

The Scientific World Journal
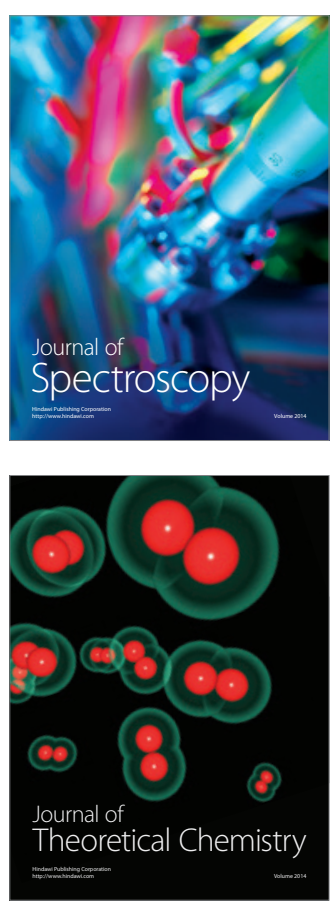
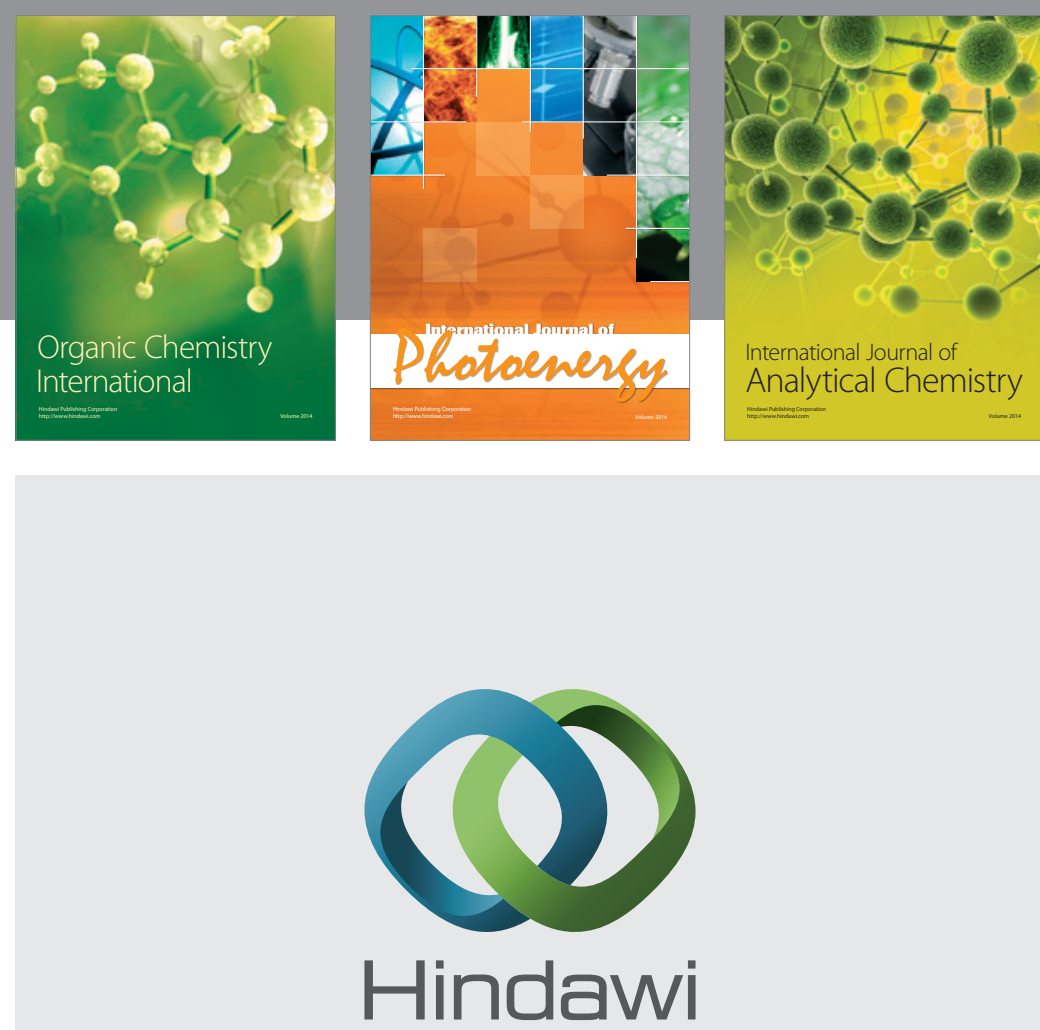

Submit your manuscripts at

http://www.hindawi.com
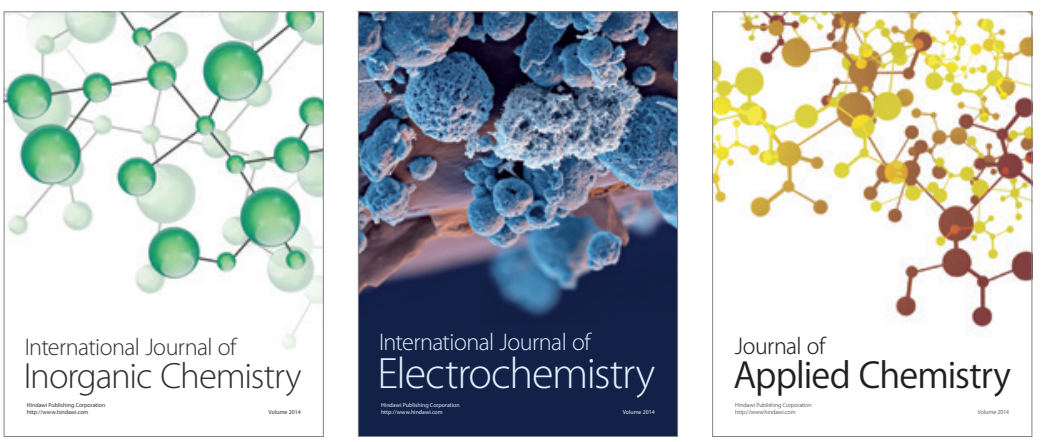

Journal of

Applied Chemistry
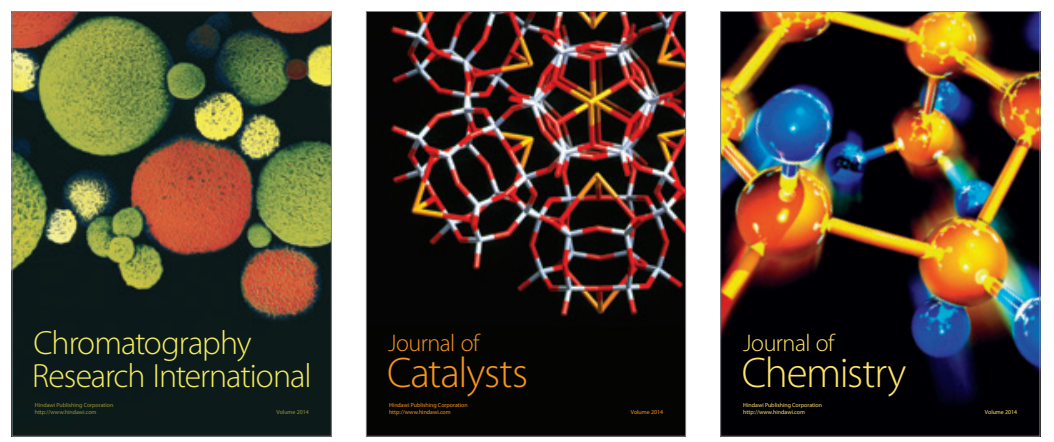
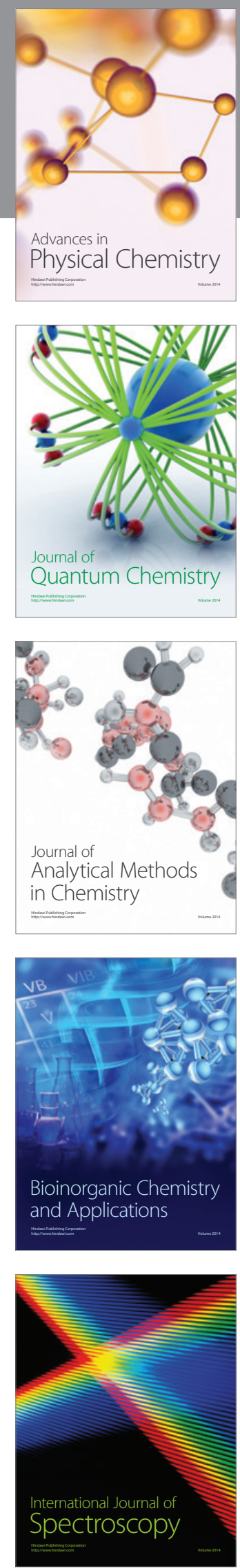